\title{
Trade Facilitation and Economic Growth in Developing Countries: Using A Static and Dynamic Framework
}

\author{
Sheereen Fauzel \\ University of Mauritius, Reduit, Mauritius \\ E-mail: s.fauzel@uom.ac.mu
}

Received: July 26, 2017 Accepted: August 23, 2017

doi:10.5296/ber.v7i2.11883 URL: https://doi.org/10.5296/ber.v7i2.11883

\begin{abstract}
Analysing the literature, it is found that empirical evidences on the link between trade facilitation and economic growth for developing countries is very scarce. The present study investigated whether trade facilitation has contributed to the economic growth of a sample of 23 developing countries over the period 2007-2014. Results from the analysis highlight the importance of trade facilitation as a crucial determinant of development. Moreover, even trade levels have demonstrated to have an important role to play in boosting growth levels. Private investment is also seen to be an important driver of growth and the importance of education, are also acknowledged by the results. The GMM estimates confirmed these results and further indicated the presence of dynamism in growth modeling. Moreover, the granger causality test shows that there is a uni directional causality flowing from trade facilitation to economic growth.
\end{abstract}

Keywords: Trade facilitation, Economic growth, General Methods of Moments (GMM)

JEL: F1, O4, C5

\section{Introduction}

Trade Facilitation is regarded as extremely important as it not only boosts the level of trade but also helps economies to attain sustainable and broad based economic growth. By increasing the level of trade, trade facilitation measures leads to the creation of jobs and income opportunities and thus lead to poverty alleviation. Numerous countries have showed that a vibrant export sector and easy access to imports can have significant contribution to economic growth and poverty reduction. (Rippel, 2011)

While trade facilitation is seen to be extremely important for growth, it is noted that in the African region there is still a lot of work to be done in this direction. It is observed that developing countries and mostly Africa's trade performance has been frail, whereby the 
intra-trade is the least compared to other regions. Referring to the UNECA report, African Heads of State and Government met in January 2012 and came up with the Action Plan for Boosting Intra African Trade (BIAT) and the establishment of the Continental Free Trade Area (CFTA) by 2017. Among the areas discussed, was trade policy, trade facilitation, productive capacity, trade related infrastructure, trade finance, trade information and factor market integration. Though decision makers and economists acknowledge the importance of trade facilitation measures in fastening trade levels, productivity and economic development, yet this has received inadequate interest in the literature. Moreover most available research tends to in the form of case studies. Research using panel data set for sample of countries has been very scarce particularly in the developing countries context. Planners need assistance based on solid empirical grounds, to support them in their decision to improve trade facilitation and build up new infrastructure in this direction. Hence, research on the aspect of trade facilitation is believed to yield interesting insights about the debate and to fill a gap in the body of literature.

This study thus examines the growth impacts of trade facilitation using panel data estimation for a sample of 23 developing countries including 20 African countries over the years 2007-2014. The sample has been determined based on data availability mainly for the logistic performance index as computed by the World Bank as a measure of trade facilitation. To take into consideration that economic growth is a dynamic phenomenon, it uses a dynamic panel data framework, namely the Generalised Methods of Moments (GMM). Moreover panel causality tests are also performed to consolidate the results.

Section 2 reviews the literature while Section 3 specified the preferred model and elaborates on data sources. Section 4 presents the results and Section 5 provides a summary of finding and policy implications.

\section{Literature Review}

Trade and economic growth has a strong relationship and this is being supported by empirical findings. For instance, the World Bank concludes that: "Trade can be a powerful force for growth and poverty reduction. Countries that have increased the share of trade in their GDP have grown faster and reduced poverty more rapidly". Hence, more trade in developing countries and therefore in African countries will contribute to increase growth. On the other hand, trade will increase if there is significant trade facilitation in the economies.

Regarding trade facilitation from the WTO perspective, it is found that it is more related to transactions at the border, such as documentary requirements, transparency of customs clearance and transit procedures, and disciplines on fees and taxes. The is referred to as the traditional view of trade facilitation and is motivated to improve border and transit management procedures and their implementation and thereby remove obstacles to trade in goods at the border; less attention is paid to "behind and between the border" issues (Rippel, 2011). Moreover, trade facilitation is referred to the simplification, harmonisation, standardisation and modernisation of procedures and associated information flows required to move goods across borders. In addition to that, trade facilitation is seen as a mechanism to reduce the time, cost and other related barriers to trading between countries. Furthermore, 
trade facilitation also helps to maintain the integrity of borders by ensuring that the relevant laws and regulations are followed (ICF for Africa, 2015). However, there is no exact definition of trade facilitation. For instance, Perez et al (2011), has defined trade facilitation as investment in hard and soft infrastructure. Hard infrastructure is referred to highways, railroads, ports, etc. and soft infrastructure refers to transparency, customs efficiency, institutional reforms, etc. Hence, there are various perspective through which trade facilitation can be viewed. Same, is summarized below, which is an extended spectrum of trade facilitation from Rippel, 2011;

\subsection{Trade Facilitation and Economic Development}

Trade facilitation is argued to boost economic development in countries. For instance, it helps to reduce trade costs and increase competitiveness of firms, thereby leading to an improvement in export performance. As a result there is more trade and creation of jobs which can thus leads to economic growth and more importantly a reduction in poverty level. This transmission mechanism is shown below;

Empirical research on trade facilitation and economic growth is very limited. For instance, most research concentrate on how trade facilitation would result in boosting trade flows and thus one might conclude that there is an increase in economic growth. Referring to the work of Helble, Mann, and Wilson (2011), it can be concluded that a narrow set of initiatives directed at trade policy and regulatory reform had a more substantial impact on exports than larger sectoral trade or infrastructure programs. It was found that a $1 \%$ increase in aid-for-trade facilitation (of about $\$ 220$ million in 2008) relates to about US\$290 million of additional exports from the aid receiving countries.

In the investigation done by Ferro, Portugal Perez, and Wilson (2011) an analysis of the role of aid to the services sectors, such as financial services, ICT, and energy on the level of exports of manufactured goods using these services as inputs was done. The authors found that aid to the transportation and energy sectors are most effective in increasing exports of manufactured goods.

\section{Methodology}

Given that there is a lack of studies on the relationship between trade facilitation and economic growth, the present paper aim at investigating same for the case of 23 developing countries over the period 2007-2014. A standard production function derived from the augmented Solow-type model such as Mankiw, Romer and Weil, 1992, Levine and Renelt, 1992 Easterly, 2001 and Li and Liu, 2005 among other, was used in this study. The following economic model is thus specified,

$$
\text { OUTPUT }=f(L P I, T O, S E R, F D I, I N V T, P O P)
$$

Where output is total output, LPI is the logistic performance index as a measure of trade facilitation as calculated by the World Bank, TO proxies the level of openness of a country, SER is the secondary enrolment ratio and reflects the quality of labour, and INVT is domestic investment and FDI proxies' foreign direct investment of the country. 
For the econometric analysis, equation (1) is expressed as a log-linear regression, where lowercase variables are the natural log of the respective uppercase variables:

$$
\text { output }_{i t}=\alpha_{i t}+\beta_{1} \text { lpi }_{i t}+\beta_{2} \text { to }_{i t}+\beta_{3} \text { ser }_{i t}+\beta_{4} f d i_{i t}+\beta_{5} i n v t_{i t}+\beta_{6} p o p_{i t}+\mu_{i t}
$$

We use $i$ to index countries and t to index time and $\mu$ is the error term.

\subsection{Data Description}

The dependent variable output was proxied by the real Gross Domestic Product (OUTPUT) and was generated from World BANK Database. The data set covers 23 developing countries1 over the period 2007-2014. The sample size and the period of study have been selected as per data availability. To proxy trade facilitation, the logistic performance index was used (Hertel and Mirza, 2009 and Hoekman and Nicita, 2008). Trade openness and economic growth is positively correlated as per empirical and theoretical literature (Anderson et al, 2008 and Gries et al, 2012). Hence, the variable trade openness was included in the model and is the ratio of imports and exports to GDP. Moreover, Nelson and Phelps (1966) claimed that a more educated labor force would imitate frontier technology faster. Benhabib and Spiegal (1994) extended on their investigation, arguing that a more educated labor force would also innovate faster. Also, Lucas (1988) and Mankiw, Romer, and Weil (1992) observed that the accumulation of human capital could increase the productivity of other factors and thereby raise growth. Hence, to revisit this relation, the secondary enrolment ratio was included in the model to measure the causal link between education and economic growth.

Private investment (INVT), has been measured as the Gross Fixed Capital Formation by the private sector as a percentage of GDP and the data was available from International Monetary Fund's International Financial Statistics, World Development Indicators (various issues), African Development Bank, Selected Statistics on African Countries (2000) and the World Investment Directory published by the United Nations. It is observed that economic models of endogenous growth have examined the effect of FDI on economic growth through the diffusion of technology (Barro, 1990; Barrel and Pain, 1997). FDI is seen to promote economic growth through creation of dynamic comparative advantages that leads to technological progress (Balasubramanyam et al., 1996; Borensztein et al., 1998). Hence, FDI as a percentage of GDP has been included in the model. Lastly, population size can have an impact on growth. Hence, the size of the population is added. Data has been obtained from the World Bank database.

\section{Analysis of Results}

\section{Static Panel analysis}

In this section, the aim is to make a comparative analysis of the results obtained of the different techniques used. For instance, the main limitation of the OLS regression is that the estimates are likely to be biased, inefficient and/or inconsistent when they are applied to pooled data. This is because the errors for regression equations estimated from pooled data 
using OLS procedure and pooled data tend to generate various complications (Hicks 1994). For instance, the errors tend to be correlated across nations and also errors tend to be heteroschesdastic, such that they may have differing variances across ranges or sub sets of nations (Podesta, 2002). Hence, because of the short comings of pooled OLS data techniques are recommended. The paper still reports, for comparative purposes and to get a broad overview these all the estimates.

Hence, both static and dynamic (Generalised Methods of Moments) techniques have been used to gauge the relationship between trade facilitation and level of economic performance. Actually the use of panel data allows to control for unobserved cross country heterogeneity and also to investigate dynamic relations. Generalized Method of Moments (GMM) is an estimation procedure that allows economic models to be specified while avoiding often unwanted or unnecessary assumptions, such as specifying a particular distribution for the errors. One of the main advantages of GMM is that it allows estimation in systems where the number of unknowns is smaller than the number of moment conditions, and to test whether the moment conditions hold (all conditions not significantly different from 0) (Kevin Shepard, lecture notes on GMM). Also this method is robust to heteroscedasticiy and distributional assumptions.

In table 1 below, column two shows the results for pooled OLS, while column 3 and 4 shows estimates for Fixed and Random effects respectively.

Table 1. Dependent variable output $=\log$ OUTPUT

\begin{tabular}{|l|l|l|l|}
\hline Variable & Pooled OLS & Fixed Estimates Effect & Random Estimates Effect \\
\hline Constant & -0.821 & -3.675 & 5.621 \\
& $(-0.471)$ & $(-0.803)$ & $(3.194) * * *$ \\
\hline Lpi & 2.069 & 0.391 & 0.459 \\
& $(3.324)^{* * *}$ & $(2.708)^{* * *}$ & $(3.244)^{* * *}$ \\
\hline To & 0.713 & 0.255 & 0.169 \\
& $(2.992)^{* * *}$ & $(2.974)^{* * *}$ & $(2.107)^{* *}$ \\
\hline Ser & 1.015 & 0.463 & 0.713 \\
& $(7.492)^{* * *}$ & $(3.439)^{* * *}$ & $(8.674)^{* * *}$ \\
\hline Fdi & -0.139 & -0.011 & -0.020 \\
& $(-1.820)$ & $(-0.530)$ & $(-1.032)$ \\
\hline Invt & 0.298 & 0.195 & 0.197 \\
& $(1.595)$ & $(3.289)^{* * *}$ & $(3.355) * * *$ \\
\hline Pop & 0.096 & 0.576 & -0.088 \\
& $(1.810)^{* *}$ & $(1.799)^{* * *}$ & $(-0.762)$ \\
\hline $\mathrm{R}^{2}$ & 0.50 & 0.68 & 0.48 \\
\hline Hausman Test & & & $\mathrm{p}>$ chi square $=0.0475$ \\
\hline
\end{tabular}

Coefficients estimates and $\mathrm{t}$ values in parentheses are indicated above. The quantities in brackets are the heteroskedastic robust t/z-values. $* * *, * * *$ indicate level of significance at $1 \%, 5 \%$ and $10 \%$ respectively.

In the case of the pooled time series estimation (refer to column 2 of table 1), the output 
elasticity of trade facilitation is reported to be positive and statistically significant. Such is also the case for trade openness thus giving a priori support of the hypothesized links (Fauzel, 2016). Human capital, as expected, is an important ingredient to economic growth and is supported by the above results.

\subsection{Panel Analysis}

\section{Fixed Effects estimates}

The use of the Hausman test is used to test the use of a random or fixed effect estimator. Actually, the Hausman test tests the null hypothesis that the coefficients estimated by the efficient random effects estimator are the same as the ones estimated by the consistent fixed effects estimator. The specification test recommended the used of fixed effects model and table 1 (third column) reports the relevant estimates. Hence, the third column will be interpreted.

It is shown that trade facilitation, as proxied by the logistic performance index, has had a positive and important contribution to economic growth of the developing countries included in the sample. In fact the coefficient of 0.39 , a measure of output elasticity, means that a one percent increase in trade facilitation contributes to 0.39 percent increase in the GDP of developing economies. This result thus confirms the argument put forward by Rippel, 2011. Trade facilitation provide significant opportunities for developing countries as it helps to increase the benefits from open trade, and also contribute to economic growth and poverty reduction. Trade facilitation in terms of removing trade barriers has contributed in the expansion of global trade after the conclusion of the trade negotiations of the Uruguay Round in 1994 and the subsequent establishment of the World Trade Organization (WTO). Moreover, it can be argued that the transmission mechanism through which trade facilitation leads to economic development is mainly through the fact that trade facilitation reduces trade costs, thereby increasing firms' competitiveness and boost export performance. As a result there is more trade which leads to job creation and income opportunities and thus results in economic growth and development.

Moreover, from the results it is noted that trade openness leads to a positive and significant impact on economic growth. The results confirms those of Romer (1993), Grossman and Helpman (1991) and Barro and Sala-i-Martin (1995) among others, who argue that countries that are more open have a greater ability to come up to leading technologies of the rest of the world. Also, Chang, Kaltani, Loayza (2005) highlighted that openness promotes the efficient allocation of resources through comparative advantage, allows the dissemination of knowledge and technological progress, and also encourages competition in domestic and international markets. Regarding the human capital variable, it is noted that this variable too has the expected sign thereby confirming the existing literature on the link between human capital and economic growth. This result is in line with Acemoglu, Aghion, and Zilibotti (2003). Although the result concerning the importance of trade facilitation as a determinant of economic growth appears practical, however it is debatable whether the estimated model is unduly restrictive. 
In dynamic panel data models, due to potentially endogenous estimators the results of the OLS estimation may be biased upwards while the results of the fixed-effects estimation may be biased downwards. The System GMM results should be somewhere in between both biased results (Buss et al, 2012).

\subsection{Dynamic Panel Data Regression}

Nevertheless there might still be the possibility of endogeneity of the dependent variable and the loss of dynamic information even in panel data framework as growth rates of the previous year may affect current year's level of income. GDP can be adjusted with time and thus economic growth is dynamic in nature and should be modeled as such (Seetanah, 2009). To incorporate the above argument and adjustment process, the following model can be written;

$$
\text { output }_{i t}-\text { output }_{i t-1}=\lambda\left(\text { output }^{*}{ }_{i t}-\text { output }_{t-1}\right)
$$

The above equation is showing the adjustment process period t to its target growth level, output ${ }^{*}$ it. The coefficient $\lambda$ shows of speed of adjustment in the system and is between 0 and 1. The latter can be estimated by the following equation

$$
\text { output }{ }_{i t}=\alpha_{t}+\beta x_{i t}+\mu_{i t}
$$

Where $\mathrm{x}_{\mathrm{it}}$ is equal to the vector of explanatory variables, that is $\mathrm{x}=$ $[l p i$, to, ser, $f d i, i n v t, p o p]$ and $\beta$ s are the respective coefficients. $\alpha_{\mathrm{t}}$ is the period specific intercept term and $\mu_{\mathrm{it}}$ is the time variant idiosyncratic error term.

Combining equation 3 and 4 above results in

$$
\text { output }_{i t}=\alpha_{t}+(1-\lambda) \text { output }_{i t-1}+\lambda \beta x_{i t}+c_{i}+\varepsilon_{i t}
$$

$c_{i}$ is the unobserved country specific and time invariant effect, that is the unobserved fixed effects.

The above can also be written in first differences which in fact eliminate the country specific and time-invariant component, $\mathrm{c}_{\mathrm{i}}$.

$$
\Delta_{\text {output }}{ }_{i t}=\alpha_{t}+(1-\lambda) \Delta o u t p u t_{i t-1}+\lambda \beta \Delta x_{i t}+\Delta \varepsilon_{i t}
$$

A problem of endogeneity exists since output $\mathrm{t}_{\mathrm{t}-1}$ might be endogeneous to the error terms through $\mathrm{u}_{\mathrm{it}-1}$, and hence it will be inappropriate to estimate the above by OLS. To remove this problem of endogeneity, an instrumental variable need to be used. Hence, the Generalised Methods of Moments estimators (GMM, Arellano and Bond's, 1991), first and second step respectively, can be used. In this investigation the GMM is being used. Moreover, the first step GMM estimator will be used since it has been proved to result in more reliable inferences. The asymptotic standards errors from the two step GMM estimator have been found to have a downward bias (Blundell and Bond, 1998). 


\section{Macrothink}

The results from estimating equation (5) using the Arellano-Bond (1991) first step GMM estimator are presented in table 3 below.

Table 2. Dynamic Panel Data Estimation (First Step GMM estimator)

Dependent variable output $=(\log$ of OUTPUT $)$

\begin{tabular}{|c|c|}
\hline Variable & GMM estimates \\
\hline soutput $_{\text {t-1 }}$ & $0.190 * * *$ \\
\hline$\Delta \mathbf{l p i} \mathbf{t}_{\mathrm{t}-1}$ & $0.219^{*}$ \\
\hline$\Delta$ to $t-1$ & $0.315 * *$ \\
\hline$\Delta \operatorname{ser}_{\mathrm{t}-1}$ & $0.915 * *$ \\
\hline$\Delta \mathbf{f d i} \mathbf{i}_{t-1}$ & -0.014 \\
\hline$\Delta \operatorname{invt}_{t-1}$ & $0.225^{* *}$ \\
\hline$\Delta \operatorname{pop}_{\mathrm{t}-1}$ & 0.390 \\
\hline $\begin{array}{l}\text { Diagnosis test } \\
\text { Sargan Test of Overidentifying restrictions }\end{array}$ & $\mathrm{P}>\mathrm{chi} 2=0.22$ \\
\hline Arellano-Bond test of $1^{\text {st }}$ order autocorrelation & $\mathrm{P}>\mathrm{chi} 2=0.747$ \\
\hline
\end{tabular}

*significant at $10 \%, * *$ significant at $5 \%, * * *$ significant at $1 \%$.

The z-statistics are in parentheses. The test statistics and standard errors are asymptotically robust to heteroskedasticity. The small letters denotes variables in natural logarithmic. AR (1) is the test for first order serial correlation. Sargan statistics is to test for over-identifying restrictions is valid.

The above results tends to support the results obtained in table 1 (fixed estimate regression) and confirm the view that trade facilitation has a positive and significant effect on growth level for the sample of economies used under the study. While referring to the estimate of the lagged dependent output $\mathrm{t}_{-1}$, it seems that the present output level is determined by its lagged, and is thus of a dynamic nature, adjusting to a target. Also, it represent the sign of convergence and the value of 0.19 obtained suggest that a relatively high rate of adjustment. Also the Arellano- Bond test shows that there is no autocorrelation in first differenced error terms.

\subsection{Causality Test and Reverse Effects}

To investigate whether any causal relationship exists between the different variables, the well-known Granger-Causality test is adopted. The approach adopted by Granger (1969) to the question of whether variable $\mathrm{x}$ causes variable $\mathrm{y}$ and vice versa.

The results are presented in tabular form: 
Table 3. Pairwise Granger-Causality tests

(From now on, $\mathrm{X} \Rightarrow \mathrm{Y}$ implies $\mathrm{X}$ Granger-Causes $\mathrm{Y}$ and $\Longleftrightarrow$ indicates bi-directional causality)

\begin{tabular}{|c|c|}
\hline Hypothesis & Direction of causality \\
\hline Trade facilitation and output & trade facilitation $\Rightarrow$ output \\
\hline Trade facilitation and trade openness & Trade facilitation $\longleftrightarrow$ trade openness \\
\hline Trade openness and output & Trade openness $\longleftrightarrow$ output \\
\hline Human capital and output & Human capital $\longleftrightarrow$ output \\
\hline Investment and output & Investment $\longleftrightarrow$ output \\
\hline Trade facilitation and fdi & Trade facilitation $\Rightarrow \mathrm{fdi}$ \\
\hline
\end{tabular}

Interesting results are obtained from the analysis of the Granger-Causality tests. For instance, the results of the pairwise Granger-Causality tests reveal that trade facilitation as proxied by LPI Granger-causes economic growth. However, there is no reverse causation between these two variables. Hence, it can be concluded that a uni directional causality exist between trade facilitation and economic growth. Additionally, it can be seen that trade facilitation Granger-causes trade openness and interestingly a reverse causation exists in that trade openness also appear to be a determinant of trade facilitation as well. Such a result is obtained from Seetanah et al, (2016). Moreover, there is also a bi directional causality between trade openness and economic growth. Hence, more the economies are open, the higher will be economic growth and vice versa. Bi directional causality is also obtained between human capital and economic growth and also between domestic investment and economic growth. These are in line with previous empirical works done in these directions.

\section{Conclusion}

Empirical evidences on the link between trade facilitation and economic growth for developing countries have been very scarce in the literature. The present study investigated whether trade facilitation has contributed to the economic growth of a sample of 23 developing countries over the period 2007-2014. Results from the analysis highlight the importance of trade facilitation as a crucial determinant of development. Moreover, even trade levels have demonstrated to be very important role to play in boosting growth levels. Private investment is also seen to be an important driver of growth and the importance of education, are also acknowledged by the results. The GMM estimates confirmed the above and further indicated the presence of dynamism in growth modeling.

Regarding the granger causality analysis, the positive association between trade facilitation and economic growth is further confirmed, however no reverse causation is observed here. Bi-causal relationship is obtained for the case of trade facilitation and trade openness highlighting further the importance of trade facilitation. Finally, the presence of bi-causality between human capital, private investment and income level from the sample is also noted.

Hence, these results are very important for policy implications. Investment in trade facilitation measures by the developing countries' government should be given high priority on their agenda. For instance, these governments need to allocate budget in order to meet up 
the challenges in terms of, improving telecommunications services, developing the payment and insurance systems, facilitate customs procedures whereby there are no excessive documentary requirements and improve transparency predictability and consistency.

\section{References}

Acemoglu, D., Aghion, P., \& Zilibotti, F. (2003). Vertical integration and distance to frontier. Journal of the European Economic Association, 1(2-3), 630-638.

https://doi.org/10.1162/154247603322391260

Andersen, L., \& Babula, R., (2008). The link between openness and long-run economic growth. Journal of International Commerce and Economics, 2, 31-50.

Arrelano, M., \& Bond, S. (1991). Some Tests of Specification for panel data: Monte Carlo Evidence and an application to employment equations. Review of Economic Studies, 58, 277-297. https://doi.org/10.2307/2297968

Balasubramanyam, V. N., Salisu, M., \& Sapsford, D. (1996). Foreign direct investment and growth in EP and IS countries. The economic journal, 92-105.

https://doi.org/10.2307/2234933

Barrel, R., \& Pain, N., (1999). The growth of foreign direct investment in Europe. Innovation, Investment and Diffusion of Technology in Europe: German Direct Investment and Economic Growth in Postwar Europe, Edited by. Barrel, Ray and Nigel Pain, Cambridge University Press, Cambridge, 19-43.

Barro, R. J., \& Sala-i-Martin, X. (1995). Technological diffusion, convergence, and growth (No. w5151). National Bureau of Economic Research. https://doi.org/10.3386/w5151

Benhabib, J., \& Spiegel, M. M. (1994). The role of human capital in economic development evidence from aggregate cross-country data. Journal of Monetary economics, 34(2), 143-173. https://doi.org/10.1016/0304-3932(94)90047-7

Blundell and Bond, (1998), .Initial conditions and Moments restrictions in dynamic panel data models. Journal of Econometrics, 87, 115-144.

https://doi.org/10.1016/S0304-4076(98)00009-8

Borensztein, E., De Gregorio, J., \& Lee, J. W. (1998). How does foreign direct investment affect economic growth?. Journal of international Economics, 45(1), 115-135.

https://doi.org/10.1016/S0022-1996(97)00033-0

Busse, M., \& Königer, J. (2012). Trade and economic growth: A re-examination of the empirical evidence.

Chang, R., Kaltani, L., \& Loayza, N. (2005). Openness can be good for growth: The role of policy complementarities (No. w11787). National Bureau of Economic Research.

https://doi.org/10.3386/w11787

Easterly, W., \& Levine, R., (2001). What have we learned from a decade of empirical research on growth? It's Not Factor Accumulation: Stylized Facts and Growth Models. The 
world bank economic review, 15(2), 177-219. https://doi.org/10.1093/wber/15.2.177

Fauzel, S., 2016. Trade and Inclusive Development in Mauritius: Evidence from a Dynamic Framework. Inclusive Growth and Development Issues in Eastern and Southern Africa, p.27.

Ferro, E., Portugal-Pérez, A. L. B. E. R. T. O., \& Wilson, J. S. (2011). Aid for Trade and Export Performance: The Case of Aid in Services. Where to Spend the Next Million?, 207.

Gregory, M. N., Romer, D., \& Weil, D. N. (1992). A contribution to the empirics of economic growth. Quarterly Journal of Economics, 107(2), 407-437. https://doi.org/10.2307/2118477

Gries, T., \& Redlin, M. (2012), June. Trade openness and economic growth: a panel causality analysis. In International Conferences of RCIE, KIET, and APEA, March (pp. 16-18).

Grossman, G. M., \& Helpman, E. (1991). Quality ladders in the theory of growth. The Review of Economic Studies, 58(1), 43-61. https://doi.org/10.2307/2298044

Helble, M., Mann, C. L., \& Wilson, J. S. (2012). Aid-for-trade facilitation.Review of World Economics, 148(2), 357-376. https://doi.org/10.1007/s10290-011-0115-9

Hicks A. (1994), Introduction to Pooling, in T. Janoski and A. Hicks (edited by), The Comparative Political Economy of the Welfare State, Cambridge University Press. https://doi.org/10.1017/CBO9781139174053.007

Levine, R., \& Renelt, D. (1992). A sensitivity analysis of cross-country growth regressions. The American economic review, 942-963.

Li, X., \& Liu, X. (2005). Foreign Direct Investment and Economic Growth: An Increasingly Endogenous Relationship. World Development, 33(3), 393-407.

https://doi.org/10.1016/j.worlddev.2004.11.001

Lucas, P. (1988). An approach to research based teacher education through collaborative inquiry. Journal of Education for Teaching, 14(1), 55-73.

https://doi.org/10.1080/0260747880140105

Mankiw, N. G., Romer, D., \& Weil, D. N. (1992). A contribution to the empirics of economic growth. The Quarterly Journal of Economics, CVI, 2, 407-437.

https://doi.org/10.2307/2118477

Nelson, R. R., \& Phelps, E. S. (1966). Investment in humans, technological diffusion, and economic growth. The American economic review, 56(1/2), 69-75.

Podestà, F. (2002). Recent developments in quantitative comparative methodology: The case of pooled time series cross-section analysis. DSS Papers Soc, 3(2), 5-44.

Portugal-Perez, A., \& Wilson, J. S. (2009). Why trade facilitation matters to Africa. World Trade Review, 8(03), 379-416. https://doi.org/10.1017/S147474560900439X

Rippel, B. (2011). Why trade facilitation is important for Africa.

http://siteresources.worldbank.org/INTAFRREGTOPTRADE/Resources/trade_facilitation_n ote_nov11.pdf 
Romer, P. (1993). Idea gaps and object gaps in economic development. Journal of monetary economics, 32(3), 543-573. https://doi.org/10.1016/0304-3932(93)90029-F

Seetanah, B. (2009). Using GMM framework to analyse the role of transport insfrastructure in economic growth: The African case. In 9th Global Conference on Business and Economics. https://www.kevinsheppard.com/images/5/55/Chapter6.pdf

\section{Copyright Disclaimer}

Copyright for this article is retained by the author(s), with first publication rights granted to the journal.

This is an open-access article distributed under the terms and conditions of the Creative Commons Attribution license (http://creativecommons.org/licenses/by/3.0/). 